Article

\title{
Buddhists Care: Examining the Impact of Religious Elements on Reducing Discriminatory Attitudes toward People Living with HIV/AIDS
}

\author{
Yao Song ${ }^{1}$ and Zhenzhen Qin ${ }^{2, *}$ \\ 1 School of Design, The Hong Kong Polytechnic University, Hong Kong 00852, China \\ 2 School of Journalism and Communication, Anhui Normal University, Wuhu 241002, China \\ * Correspondence: zhen.qin@connect.polyu.hk
}

Received: 30 May 2019; Accepted: 25 June 2019; Published: 28 June 2019

check for updates

\begin{abstract}
Faith-based programs have been long regarded as influential social approaches to form positive attitudes to human immunodeficiency virus (HIV)/acquired immunodeficiency syndrome (AIDS) within the last few decades. However, recent scholars argue that religions serve a double role in supporting HIV-infected people. Moreover, relevant evidence is mainly collected from studies among participants of the Western religious traditions, such as Christianity. This study applies the theory of the attitude formation model to examine Buddhist factors impacting discriminatory attitudes towards HIV/AIDS and the causal path to positive behavior intention. To investigate its underlying mechanism, Buddhist elements, as an important antecedent, were introduced in the advertisement against HIV/AIDS-related discrimination to influence people's attitudinal reaction. Results show that Buddhist advertising could significantly increase perceived religiosity and compassion. Then, both perceived religiosity and compassion jointly increase anti-prejudical attitudes towards HIV-infected people and have a positive impact on interaction intention at the end.
\end{abstract}

Keywords: Buddhist Compassion; HIV/AIDS-related Discrimination; HIV/AIDS-related Stigma; Buddhist Advertising; Public Health

\section{Introduction}

Social attitudes have increasingly continued to threaten global human immunodeficiency virus (HIV)/acquired immunodeficiency syndrome (AIDS) prevention effectiveness (Sayles et al. 2009). Though faith-based programs have been long regarded as influential social approaches to form positive responses to HIV/AIDS (Blevins et al. 2019), recent scholars argue that religions underpin prejudice while assisting (Anderson et al. 2008; Blevins 2015). Moreover, relevant evidence is mainly collected from studies among participants of Western religious traditions, such as Christianity. Other major religions, like Buddhism, have seldom been empirically studied on the discourse of attitudinal reaction to HIV/AIDS (Clobert et al. 2015).

Buddhism has been associated with the doctrine of cultivating compassion to attenuate prejudice (Davidson and Harrington 2002). However, prior research reports that Buddhists present a controversial response to HIV/AIDS (Moyo and Ying-Ling 2014; Engstrom 2005; Malamuth et al. 1980; Songwathana and Manderson 2001; Kittikorn et al. 2006). This urges investigators to conduct a relevant study of the empirical effects of Buddhist factors on HIV/AIDS-related discrimination.

On the other hand, for about two decades, communicative approaches of advertising have been widely adopted to educate people with HIV/AIDS-related knowledge and contribute to attitude formation towards HIV-infected people (Hutchinson et al. 2007; Hendriksen et al. 2009; Ackerson et al. 2012). Faith-based factors, such as religiosity, have seldom been studied in the research into advertisements against HIV/AIDS-related discrimination. 
To address the above issues, this study applies the theory of the attitude formation model to examine Buddhist factors impacting discriminatory attitudes towards HIV/AIDS and the causal path to positive behavior intention. The significance of this study is two-fold. First, it introduces the Buddhist elements presented in advertisements against HIV/AIDS-related discrimination as an important antecedent in influencing people's attitudinal reaction. Second, the current study provides empirical evidence of Buddhist reactions to enrich the current literature of faith-based responses to public health.

\section{Literature Review}

\subsection{HIV/AIDS-Related Discrimination and Advertising}

Undoubtedly, HIV/AIDS is one of the world's most serious public health challenges. Up to 2017, the Joint United Nations Programme on HIV/AIDS (UNAIDS) reported that 36.9 million people across the world were living with HIV affection (UNAIDS 2018). Over the past decade, medical breakthroughs in HIV/AIDS therapy have transformed HIV infection from a fatal diagnosis into a manageable chronic illness (Jensen-Fangel et al. 2004), but social attitudes towards HIV/AIDS continue to threaten global HIV/AIDS prevention effectiveness (Sayles et al. 2009). HIV/AIDS-related discrimination has been regarded as a barrier to HIV treatment and related care (Genberg et al. 2008; Nyblade and MacQuarrie 2006). For instance, discrimination has been cited as the main factor for why people are reluctant to access HIV/AIDS tests and medical care (World Health Organization and Unicef 2015). On the other hand, violence against people living with HIV/AIDS caused by discrimination has exacerbated the problem (Dlamini et al. 2007).

HIV/AIDS-related discrimination has been defined as prejudice, negative attitudes, and abuse directed at people diagnosed with HIV and AIDS (Kitara and Aloyo 2012). Internationally, discrimination has been voiced along with the HIV/AIDS pandemic. A recent survey shows that over $50 \%$ of participants report involving discriminatory attitudes towards people living with HIV or AIDS (UNAIDS 2015). To address this issue, scholars have exerted efforts to understand the antecedents and mediatory process of such discriminations to seek possible interventions (Parker and Aggleton 2003; Genberg et al. 2008). Among those, communicative determinants have been studied as crucial approaches to educate people with HIV/AIDS-related knowledge and contribute to attitude formation towards HIV-infected people (Hutchinson et al. 2007; Hendriksen et al. 2009; Ackerson et al. 2012). Scholars argue that informative inputs foster informal discussions about HIV/AIDS to eliminate the fear, and then decrease discrimination (Genberg et al. 2009; Ackerson et al. 2012; Khuat et al. 2004). However, the in-depth mechanism of how communicative approaches form attitudes to decrease discrimination towards HIV/AIDS remains ambiguous for researchers to further investigate proper intervention programs.

Recently, it has been suggested that access and exposure to HIV/AIDS-related advertisements constitute an effective tool of communication to combat HIV/AIDS-related discrimination (Ackerson et al. 2012; Peltzer et al. 2012). Within this context, organizations and government bodies promote various advertising programs to educate the public about the transmission and prevention of HIV/AIDS (Johnny and Mitchell 2006). Current research into HIV/AIDS advertisements mainly focus on demographic variance (e.g., different racial groups) (Khuat et al. 2004), general emotional motivation (e.g., fear) (Scalvini 2010), and knowledgeable education (Fuqua 2002). An intervention may incorporate mass media communication to elevate its value and reduce discrimination associated with HIV, and hence improve multiple outcomes such as mental health status, substance use, social isolation, and employment (Tran et al. 2019). Though religious beliefs have been discussed as a crucial factor to influence public health (Blevins et al. 2019; Chatters 2002; Idler 2015), the role of faith-based determinants have seldom been studied in the research into advertisements against HIV/AIDS-related discrimination. 


\subsection{Buddhist Compassion and HIV/AIDS-Related Discrimination}

In the past decade, the role of religion in influencing international public health has been increasingly important (Blevins 2018; Blevins et al. 2016). However, recent scholars argue the paradoxical influence of religious beliefs. In particular, it acts as a double-edged sword in supporting people living with HIV/AIDS. Blevins (2015) proposes that Christianity and Islam in Africa serve as a driver of discriminatory attitudes towards others (e.g., sex workers) while encouraging supportive HIV programs. Also, negative attitudes of the clergy towards HIV prevention education has been reported recently (van Dyk 2017).

On the other hand, most prior research into religion-based health issues are mainly from studies among participants of the Western Christian tradition; additional investigations on Islam and Hinduism are limited in number. Among those major religions, Buddhism has been characterized by the doctrine of cultivating compassion for all living beings to advocate helping behavior and non-violence. Buddhist teachings, deity figures and relevant practices, such as animal release (Shiu and Stokes 2008), are used to help people shape a caring, more considerable and compassionate personality (Davidson and Harrington 2002; Schroeder 2002). Moreover, prejudice is unstressed in Buddhism (Clobert et al. 2017). Relevant studies have confirmed that Buddhist belief is significant in decreasing discriminatory attitudes towards other social groups (Clobert et al. 2015) since Buddhism emphasizes holistic thinking about the world through empathizing with all living beings, especially those in need of help (Davidson and Harrington 2002).

Nevertheless, the Buddhist influence on HIV/AIDS-related discrimination remains ambiguous. Some studies indicate that Buddhists tend to support HIV/AIDS treatment and care (Moyo and Ying-Ling 2014; Engstrom 2005; Malamuth et al. 1980) while a small number of studies argue that HIV/AIDS is viewed as an immorality and a sinful act in Buddhist philosophy to increase stigma and discrimination (Songwathana and Manderson 2001; Kittikorn et al. 2006). Consequently, it is necessary to test the role of Buddhist concepts in implicitly activating anti-discrimination towards HIV/AIDS in the context of advertising.

\subsection{Buddhist Symbolic Elements in Advertising}

Religious beliefs play a significant role in shaping values and attitudes towards real life; for this reason, elements with symbolic meanings in specific religions have been largely exploited in advertising to influence people's attitudinal behaviors (Song and Qin, 2019; Taylor et al. 2010; Dotson and Hyatt 2002; Nardella 2012). Scholars construe that the mindset of religious belief elicited by religious symbols influences people's information process of advertising objects to form purposive attitudes (Naseri and Tamam 2012).

Recent studies further reveal the role of religiosity in influencing religion-informed attitudinal reactions. Religiosity refers to the degree to which beliefs in specific religious values and attitudes are held and practiced by an individual, "incorporating cognitive, emotional, motivational, and behavior aspects" (Hackney and Sanders 2003; Naseri and Tamam 2012). Scholars have confirmed that religiosity plays a mediating role in the relationship between relative and contextual variables, and behavior intention in Islam (Alam et al. 2011; Hassan Fathelrahman Mansour and Diab 2016). In this view, the perceived religiosity predicts attitudes and consequent behaviors directed at advertising objects. For example, religiosity predicts bystanders' intention to prevent domestic violence (Muralidharan et al. 2018). Nevertheless, other major religions, like Buddhism, have seldom been investigated in the context of advertising.

As aforementioned in Section 2.2, Buddhist doctrinal teachings advocate compassion through empathizing with all living beings in need of help (Davidson and Harrington 2002), which are visualized and presented as many symbolic elements with figurative quality in sacred sites and in media (Miller 2015). For example, in Mahayana Buddhism, a Bodhisattva refers to the deity with a compassionate mind to attain Buddhahood. It embodies the meaning of selfless love, which is the supreme symbol of radical compassion (Mair and Blofeld 2006). Various figures of Bodhisattva are 
exploited as elements in visual media to enlighten people with Buddhist meanings (Patry Leidy 1252). It has been suggested that religiosity tends to be reinforced through a cognitive process of such symbolic information to construct attitudes for consequent moral behaviors (Winchester 2017; Bychkov 2019). Though printed media has been reported as a source to construct Buddhist religiosity (Yeung and Chow 2010), the empirical effects of Buddhist symbolic elements on religiosity and behavioral reaction are limited in current literature, especially in the context of HIV/AIDS-related discrimination.

\subsection{Attitude Formation Model and Advertising against HIV/AIDS-Related Discrimination}

The study of attitude formation has been conducted in social psychology for years (Anderson 1971). Attitudinal constructs have been regarded as one of the fundamental determinants to predict behavior actions towards various aspects of our social environment, such as the response to HIV/AIDS. According to the theory of attitude formation model, three components of affect, behavior, and cognition significantly construct an individual's attitude structure (Breckler 1984). The tripartite model has been applied in a number of persuasive advertising studies for behavior prediction (Fishbein and Ajzen 2011; Bagozzi 2006). Emotional (Unger 1995) and cognitive (Manoj 2015; Min Han 2004) factors play significant roles in forming positive attitudes towards advertising objects. However, limited research addressing the attitudinal response to public health, especially for HIV/AIDS-related discrimination, has applied the attitude formation model to construct positive attitudes.

Consequently, following this model, an advertisement against HIV/AIDS-related discrimination that employs a Buddhist symbolic element will elicit emotional perceptions of compassion and the cognitive process of religiosity to form positive attitudes against prejudice and predict consequent behavior to support and care for those HIV-infected people in need of help.

\section{Hypotheses and Research Framework}

According to the relevant literature in Section 2, we hypothesized that advertising with Buddhist symbolic elements, compared with advertising without Buddhist symbolic elements, could significantly promote an individual's anti-prejudicial attitude and finally influence interaction intention towards HIV-infected people. Also, the relationship is mediated by two independent factors: perceived religiosity and compassion. To sum up, we had the following hypotheses:

Hypothesis 1 (H1). An individual would have a higher perceived religiosity when exposed to advertising with Buddhist symbolic elements.

Hypothesis 2 (H2). An individual would have higher compassion towards HIV-infected people when exposed to advertising with Buddhist symbolic elements.

Hypothesis 3 (H3). The perceived religiosity significantly influences an individual's anti-prejudice towards HIV-infected people.

Hypothesis 4 (H4). Compassion significantly influences an individual's anti-prejudice towards HIV-infected people.

Hypothesis 5 (H5). Anti-prejudice significantly influences an individual's interaction intention with HIV-infected people.

In order to empirically prove the significant role of Buddhist advertising against HIV/AIDS-related discrimination in influencing an individual's anti-prejudice, their interaction intention with HIV-infected people, and the underlying mechanism, related experiments were conducted to address and validate the above relationship. Figure 1 depicts the theoretical relationship and the five hypotheses (H1-H5) in the current study. 


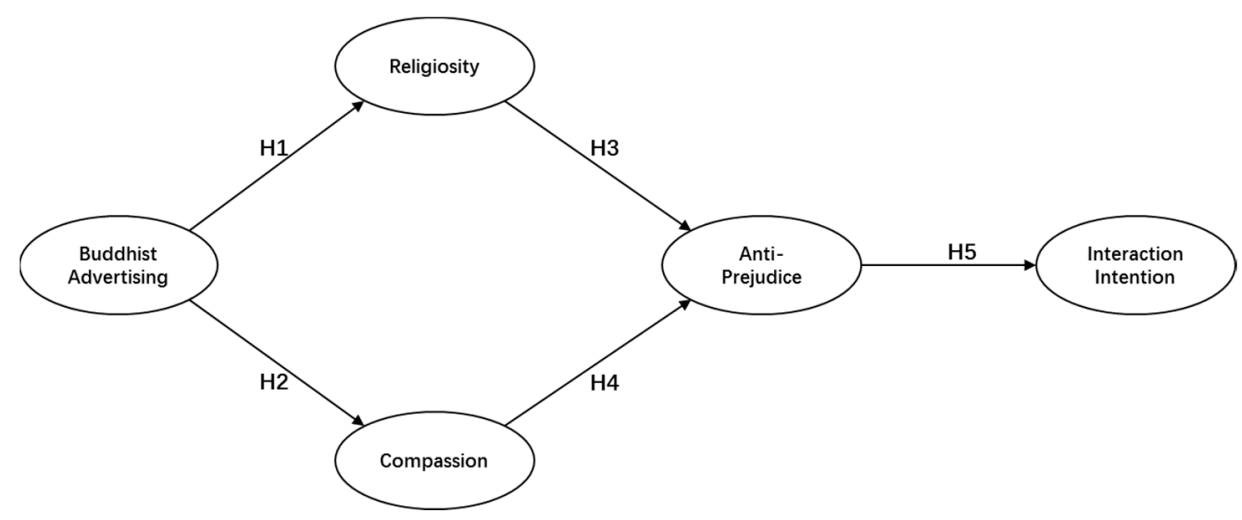

Figure 1. The research framework of the current study.

\section{Research Methods}

\subsection{Measurement Items}

As for the measurement items of different factors, a nine-point Likert scale was used to estimate different constructs. To specify, the measurement items or scales were adapted from previous related studies (Table 1). Compassion for people with HIV was estimated by an entire three-item Likert scale ((Coursey and Pandey 2007); 1 = Strongly Disagree, 9 = Strongly Agree). Perceived religiosity was estimated by an entire five-item Likert scale retrieved from Putney and Middleton (1961) (1 = Strongly Disagree, 9 = Strongly Agree). Following the adapted suggestions (St Lawrence et al. 1990), the anti-prejudice attitude was measured on five items from the relevant work (Malamuth et al. 1980). Finally, interaction intention towards people with HIV was measured by an entire three-item Likert scale adapted from a prior study on HIV stigma ((Li et al. 2006); 1 = Strongly Disagree, $9=$ Strongly Agree). Table 1 shows that the Cronbach's alpha ranged from 0.824 to 0.914 , suggesting the items are consistent and reliable in the current study.

Table 1. Measurement items and their reliability in the current study.

\begin{tabular}{|c|c|c|}
\hline Sources & Items & $\begin{array}{c}\text { Cronbach's } \\
\text { Alpha }(\alpha)\end{array}$ \\
\hline $\begin{array}{l}\text { Religiosity } \\
\text { (Putney and Middleton 1961) }\end{array}$ & $\begin{array}{l}\text { Buddhism forms an important basis for the kind of person I want to be } \\
\text { My ideas on Buddhism have a big influence on my view in other areas } \\
\text { Were I to think about Buddhism differently, my whole life would be } \\
\text { very different } \\
\text { I often think about Buddhist matters } \\
\text { Buddhism is one of the most important parts of my philosophy of life }\end{array}$ & 0.896 \\
\hline $\begin{array}{l}\text { Compassion } \\
\text { (Coursey and Pandey 2007) }\end{array}$ & $\begin{array}{l}\text { It is difficult for me to contain my feelings when I see people in illness } \\
\text { I am often reminded by daily events about how dependent we are on } \\
\text { one another } \\
\text { I have compassion for people in need who are unwilling to take the } \\
\text { first step to help themselves }\end{array}$ & 0.824 \\
\hline $\begin{array}{l}\text { Anti-Prejudice } \\
\text { (Malamuth et al. 1980) }\end{array}$ & $\begin{array}{l}\text { HIV people deserve sympathy and understanding } \\
\text { HIV people deserve the best medical care possible } \\
\text { HIV has been traumatic for affected people } \\
\text { HIV people have a lot of pain and suffering } \\
\text { HIV people are safe to others }\end{array}$ & 0.880 \\
\hline $\begin{array}{l}\text { Interaction Intention } \\
\text { (Li et al. 2006) }\end{array}$ & $\begin{array}{l}\text { If I met HIV people, I am willing to strike up a conversation with them } \\
\text { I would continue the friendship with a HIV-affected friend } \\
\text { I am willing to work in the same office with HIV people }\end{array}$ & 0.914 \\
\hline
\end{tabular}

\subsection{Stimuli and Pilot Study}

Regarding the stimuli and experiment design, a between-subjects experiment was conducted to address the hypotheses. It contained two different scenarios of advertising against HIV/AIDS-related discrimination: advertising with Buddhist elements and advertising without Buddhist elements. Then, 
one professional advertising designer was recruited to make two types of advertising (for experiment stimuli, see Figure 2a,b).

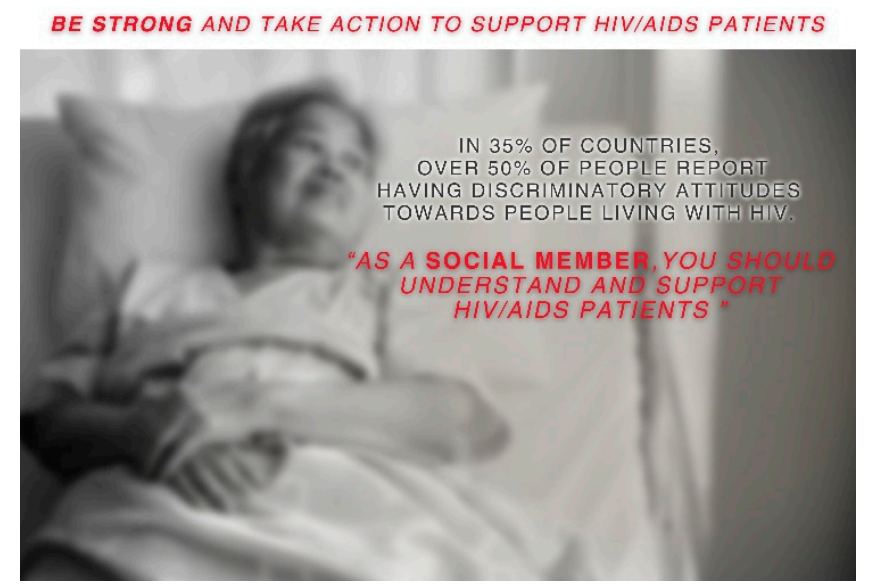

(a)

BE DEVOUT AND TAKE ACTION TO SUPPORT HIVIAIDS PATIENTS

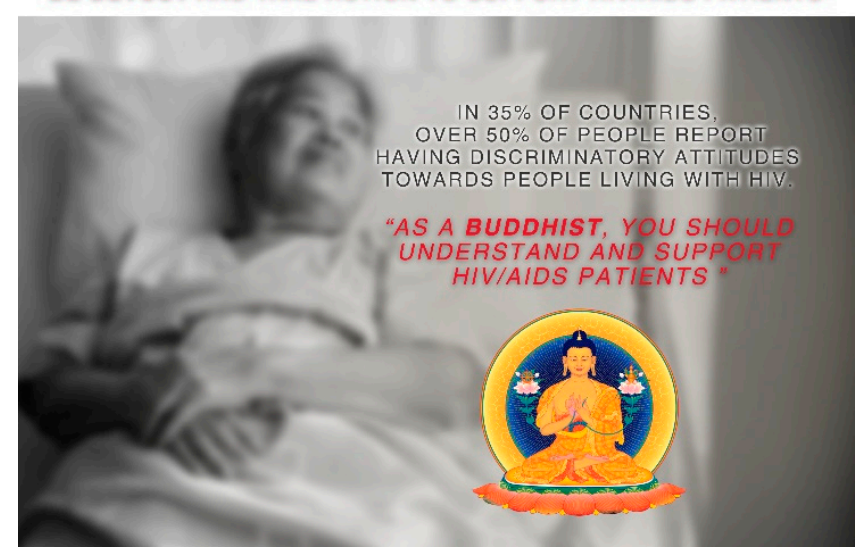

(b)

Figure 2. (a) Advertising without Buddhist elements. (b) Advertising with Buddhist elements.

To control the potential confounding effects of the experimental stimuli, the current study made sure that two advertisements have the same width, height, phrase length, color, style, and position. The only difference between these two versions was that Figure $2 \mathrm{a}$ was a general prosocial claim with the statements "be strong" and "as a social member", while Figure $2 b$ focused more from Buddhist perspective with the statements "be devout", "as a Buddhist", and a Buddhist image. The phrases "be strong", "as a social member", "be devout," and "as a Buddhist" were carefully chosen to keep the meaning relatively unchanged but Buddhist elements were introduced (Muralidharan et al. 2018). Thus, we confirmed that the only difference between the two stimuli was the Buddhist elements that we intended to introduce.

\subsection{Experiment Procedure}

In order to validate the effect of Buddhist advertising on anti-prejudice attitudes, interaction intention, and the underlying mechanism towards HIV-infected people, an experiment sample was recruited from Amazon Mechanical Turk (M-Turk) in the experiment. There are two major advantages to conducting this experiment on this platform: first, the M-Turk population has more than 480,000 individual workers from 180 countries, which could be more representative of the population to a large extent; second, it is also a valid experiment data source which could provide adequate reliability and validity in the research from various disciplines, such as religion and other 
humanity research (Rand et al. 2014; Ritter and Preston 2013; Feldman et al. 2016; Stewart et al. 2015; Daly and Nataraajan 2015).

In the current study, 100 Buddhist participants were recruited through the M-Turk platform (mean age $=34.99$ years; 66 men and 34 women). As for the experimental process, they firstly consented to participate in the experiment, and were then evenly and randomly assigned to the two scenarios mentioned earlier (Figure 2a,b). After describing the background, they were required to evaluate a prosocial advertisement. To specify, they were asked to look at the advertisement and finish the questionnaire prepared. At the end of the test, there is a manipulation check to confirm whether they were influenced by the Buddhist elements in the advertisement (the extent of their agreement with the statement, "This advertisement has Buddhist elements." 1 = strongly disagree; $9=$ strongly agree).

\section{Findings}

Statistical softwares, AMOS 25 and SPSS 22, were used to analyze all the data. There was no missing or incomplete data in the experiment. As for the manipulation check, we could find a significant difference from the result of $t$-test. Consistent with our prediction, an individual who was exposed to the advertisement with Buddhist elements (mean $=7.22)$ rated higher than those exposed to the scenario without Buddhist elements (mean $=3.52$; $\mathrm{t}(98)=-8.43, p<0.01$; Note: a $\mathrm{t}$-score is one form of a standardized test statistic in which a large $t$-score indicates that the groups are different), indicating manipulation in the experiment was successful. Before the main analysis, skewness and kurtosis of all the factors were checked (Dorić et al. 2009). The skewness and the kurtosis of all the factors ranged from -0.315 to -0.879 and from -0.877 to 0.130 , respectively. Since all values were within the threshold (Suki 2013; Dorić et al. 2009), it suggests that they are following a normal distribution. Table 2 shows the means, standard deviations (SD), and correlations of different constructs.

Table 2. Means, standard deviations (SD), and correlations of different constructs.

\begin{tabular}{ccccccc}
\hline Constructs & Mean & SD & RE & COM & ANT & INT \\
\hline Religiosity (RE) & 6.10 & 1.92 & 1.000 & & & \\
Compassion (COM) & 6.49 & 1.82 & $0.518^{* * *}$ & 1.000 & & \\
Anti-Prejudice (ANT) & 7.10 & 1.86 & $0.505^{* * *}$ & $0.779^{* * *}$ & 1.000 & \\
Interaction Intention & 6.68 & 1.96 & $0.522^{* * *}$ & $0.595^{* * *}$ & $0.672^{* * *}$ & 1.000 \\
(INT) & & & & &
\end{tabular}

Note: ${ }^{* * *} p<0.01$.

To begin with, we conducted a one-way ANOVA to explore the different effects of advertisements on the perceived religiosity and compassion towards HIV-infected people, then introduced path analysis to examine the relationship between different variables. By applying a bias-corrected confidence interval (CI) with bootstrapping (5000 resamples), AMOS could not only analyze the path coefficient but also the underlying mechanism within the model. For example, there might exist a significant mediation effect if the CI does not contain zero.

In order to control the potential influence of age and gender in the ANOVA analysis, we used them as covariate variables. One-way ANOVA showed that advertising with Buddhist elements (mean $=6.54, \mathrm{SD}=1.69)$ would raise higher perceived religiosity than advertising without Buddhist elements (mean $=5.66, \mathrm{SD}=2.04 ; \mathrm{F}(1,96)=4.80, p<0.05$; Note: the $\mathrm{F}$ value is one of the key statistics in ANOVA. It is the between group variability divided by the within group variability. A large $F$ value shows the groups are different). Thus, $\mathrm{H} 1$ was supported. As for the path analysis (advertising stimuli-religiosity-anti-prejudice), results indicated that advertising stimuli displayed a significant effect on perceived religiosity (effect $=0.219, p<0.05$ ). In addition, perceived religiosity could also significantly improve anti-prejudice towards HIV/AIDS (effect $=0.207, p<0.05$ ). In accordance with $\mathrm{H} 3$, perceived religiosity significantly mediated the effect of Buddhist advertisement on anti-prejudice $($ effect $=0.045,95 \%$ CI $(0.045,0.357))$. 
Then, we tried to explore whether Buddhist prosocial advertising could increase an individual's compassion towards HIV-infected people and whether compassion also mediated the effect of Buddhist advertising on anti-prejudice. Similar to the analysis of $\mathrm{H1}$, we also found that an individual exposed to the advertising with Buddhist elements tends to have a higher compassion level (mean $=6.80 \mathrm{vs}$. $6.18, \mathrm{SD}=1.68$ vs. $1.91 ; \mathrm{F}(1,96)=4.40, p<0.05)$. Figure 3 shows the difference in religiosity and compassion between advertising with Buddhist elements and advertising without Buddhist elements. Thus, $\mathrm{H} 2$ was validated. Path analysis indicated that advertising stimuli had a significant impact on compassion (effect $=0.204, p<0.05$ ). Furthermore, compassion had a strong positive influence on anti-prejudice (effect $=0.675, p<0.05$ ). Compassion towards HIV-infected people was a significant mediator between advertising stimuli and anti-prejudice (effect $=0.137,95 \% \mathrm{CI}(0.114,0.892)$ ).

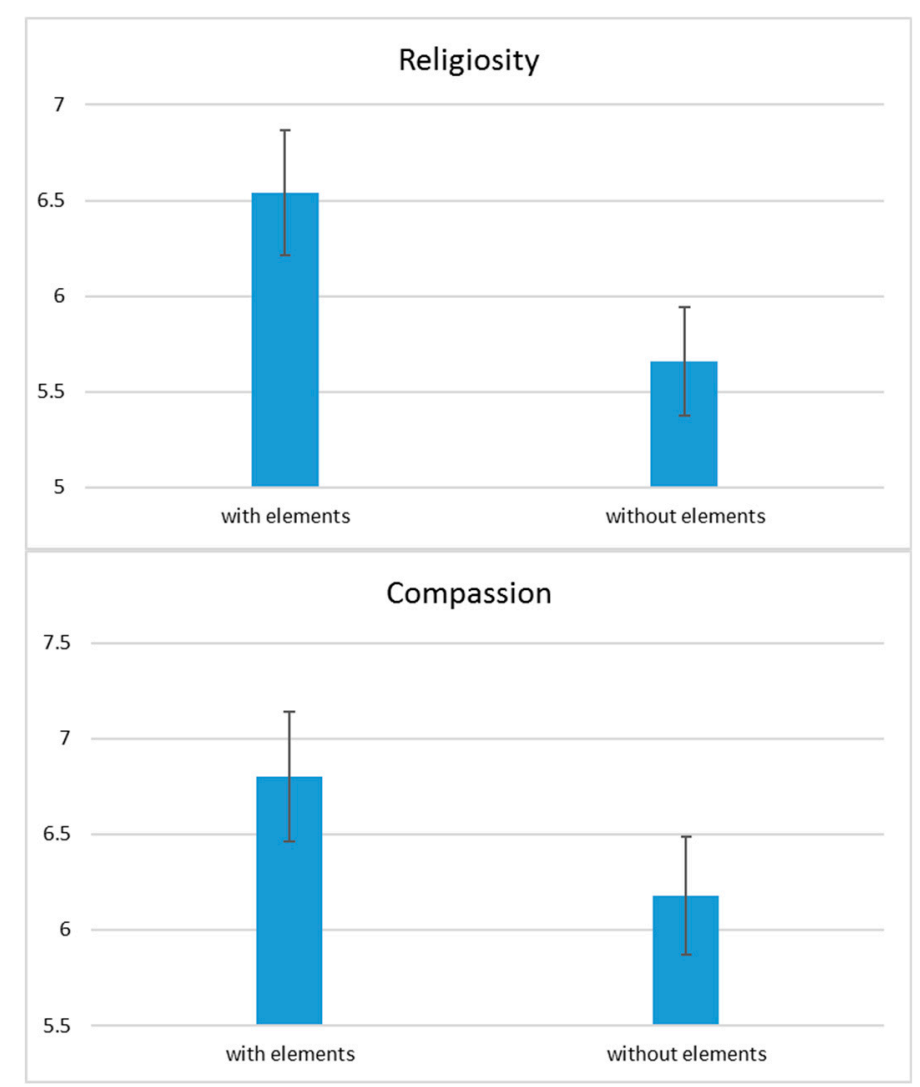

Figure 3. The difference in religiosity and compassion between advertising with Buddhist elements and advertising without Buddhist elements. Note: Religiosity and Comassion was measured by 1-9 Likert Scale: the higher value means the stronger agreement associated with the statements in the measurements.

Finally, we examined whether anti-prejudice could improve an individual's interaction intention with HIV-infected people. Supporting H5, results suggested that anti-prejudice could significantly contribute to an individual's intention to interact (effect $=0.648, p<0.05$ ). Figure 4 shows the result of the path analysis in the whole theoretical model.

To be more specific, for the advertising with Buddhist elements, perceived religiosity could increase anti-prejudice towards HIV/AIDS (effect $=0.192, p<0.05$ ), and compassion towards people with HIV/AIDS could increase anti-prejudice (effect $=0.728, p<0.05$ ). Similarly, for the advertising without Buddhist elements, compassion had a similar influence on anti-prejudice (effect $=0.242$, $p<0.05$ ), and compassion towards people with HIV/AIDS showed a similar response to anti-prejudice (effect $=0.754, p<0.05$ ). To sum up, both the religiosity and compassion towards people with HIV/AIDS could significantly improve anti-prejudice towards people living with HIV/AIDS in two scenarios. 


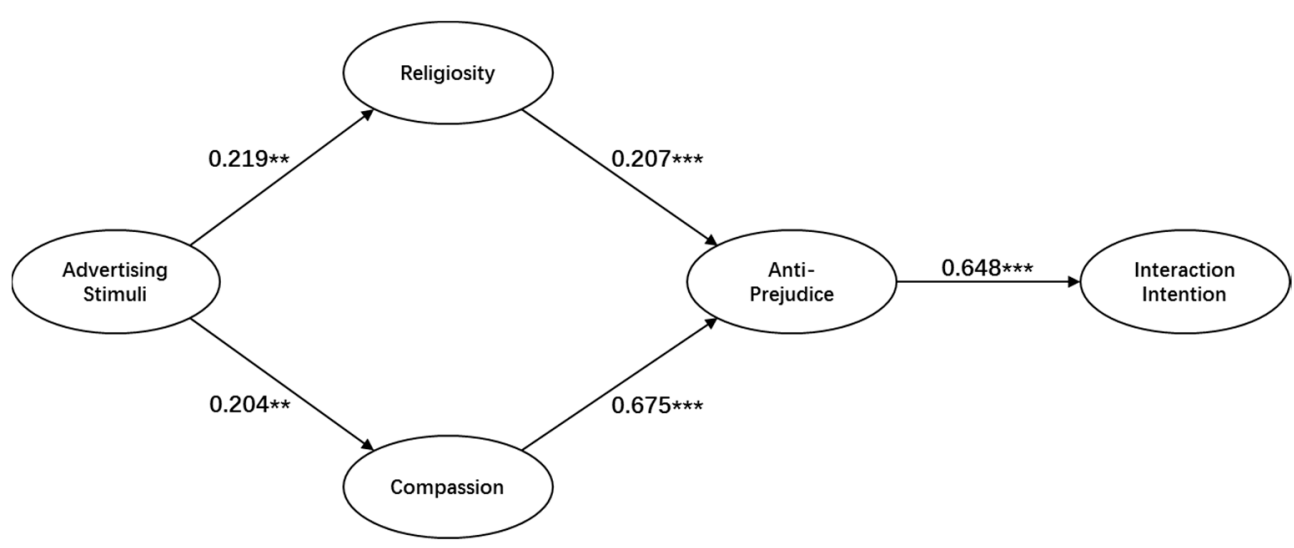

Figure 4. Path analysis of the theoretical model. Note: ${ }^{* *}$ means $p<0.05$; ${ }^{* * *}$ means $p<0.01$.

\section{Discussion, Limitations and Future Research}

Based on the theory of attitude formation model, this study aims to explore and validate the effect of advertising with Buddhist elements on an individual's anti-prejudice attitude, interaction intention towards HIV-infected people, and the mediating roles of perceived religiosity and compassion. Results show that an individual tends to have a higher level of perceived religiosity and compassion when exposed to advertising with Buddhist elements. To be specific, Buddhist advertising could significantly increase the cognitive component of religiosity and the emotional component of compassion. Then, both perceived religiosity and compassion jointly increase anti-prejudice attitudes and have a positive impact on interaction intention at the end.

This study has several theoretical contributions. First of all, though prior studies have tried to discuss the role of religions, such as Christianity, in the context of HIV/AIDS-related discrimination, limited research has discussed the effect of Buddhism, which is characterized by the doctrine of cultivating compassion for all living beings. Regarding this theoretical research gap, the current study extends the literature on the Buddhist response to public health by discussing the significant role of advertising with Buddhist elements on the attitudinal reaction to HIV/AIDS-related discrimination.

Secondly, prior research on Buddhism has shown a nuanced attitude towards HIV/AIDS-infected people. Some scholars argue that HIV/AIDS is viewed as immorality and a sinful act in Buddhist teachings (Songwathana and Manderson 2001; Kittikorn et al. 2006). However, other studies report that Buddhists tend to support HIV/AIDS-infected people because of compassionate empathy, which is one of the main Buddhist doctrinal teachings helping Buddhists to shape a caring, more considerable and compassionate personality (Davidson and Harrington 2002; Schroeder 2002). Thus, the current research tries to solve the ambiguous influence of Buddhism by providing the evidence that Buddhism-informed compassion would predict a more positive anti-prejudical attitude and have more intention to interact with those who are HIV/AIDS infected. This finding is consistent with previous research on Buddhist spirituality, acting with compassion toward all sentient beings with an awareness and appreciation of the natural world (Aung 1996; Mcgrath 2007; Watts and Tomatsu 2012).

Lastly, previous research has seldom explored the mechanism of how a Buddhist symbolic element influences an individual's attitudes and related behavioral reactions. Based on the attitude formation model, this study tries to fill this research gap by showing the mediating roles of perceived religiosity and compassion in this process. To be more specific, compassion, as an emotional factor, and religiosity, as a cognitive factor, could jointly influence anti-prejudice attitudes towards HIV-infected people. Our results empirically confirm the usefulness of religious symbolism in advertisements within the framework of the attitude formation model to predict behavioral intentions in the context of HIV/ADIS-related discrimination.

This research also has some practical implications. According to UNAIDS (2017) data, an estimated 36.9 million people were living with HIV. Among the infected people, nearly 1.8 million were children. At the same time, new HIV infections in East Asia are increasing rapidly. For example, the number 
of young infected people (aged 15-24) in the Philippines has increased by $170 \%$ while in Pakistan, their number has increased by $29 \%$. However, social attitudes have increasingly dampened HIV/AIDS prevention effectiveness (Sayles et al. 2009) and the efficiency of the anti-retroviral treatment program (Than et al. 2019). It is not only necessary but crucial to explore an effective way to promote an individual's attitude towards HIV-infected people. Concerning the important role of Buddhism in the culture of East Asia (Mair 2006), Buddhist advertising might play a significant communication role to increase an individual's attitude towards HIV-infected people and the consequent behavior to support.

There are also some limitations to the current study. For example, although we recruited Buddhists to participate in this study, we did not consider how long each participant has engaged with Buddhism; prior research has indicated that the time length of Buddhist practice might influence people's healthy behavior. It might be theoretically interesting to analyze its influence on discriminatory attitudes towards HIV/AIDS in a future study. Besides, the current study aimed to figure out the impact of Buddhist elements on people's attitudes and consequent behavioral reactions. However, the inclusion of a Buddhist image in the experiment group might have a potential confounding effect. Although we followed the suggestions on Buddhist advertising (Muralidharan et al. 2018), merely the inclusion of a Buddhist image might still potentially influence the result. Future studies would try to introduce a comparable social image in the control group to validate the conclusion of this study. Also, although the theoretical model in the current paper is based on the theory of attitude formation model (Muralidharan et al. 2018), the actual behavioral reaction (for example, the actual behavioral data) is not discussed in the current study. Indeed, the relationship between intentions and actual behavioral reactions has long attracted attention and been explored to some extent (Morwitz and Fitzsimons 2004). A future study could conduct a field experiment to collect actual behavioral data and validate the present finding. Lastly, the current study recruited 100 Buddhists and the related measurement items to explore the effect of advertising with Buddhist elements on perceptions towards HIV/AIDS. However, the sample size is relatively small, and there are many other scales on the same factor. A future study might consider applying different measurement scales and bigger sample sizes to further validate the effect of Buddhist elements not only on Buddhists, but also on general people's perceptions and related behavioral reactions.

Author Contributions: Conceptualization, research design, formal analysis, and writing—review and editing, Z.Q.; Data collection, methodology, data processing, and data curation, Y.S.

Funding: This research received no external funding.

Conflicts of Interest: The authors declare no conflict of interest.

\section{References}

Ackerson, Leland K., Shoba Ramanadhan, Monisha Arya, and Kasisomayajula Viswanath. 2012. Social Disparities, Communication Inequalities, and HIV/AIDS-Related Knowledge and Attitudes in India. AIDS and Behavior 16: 2072-81. [CrossRef] [PubMed]

Alam, Syed Shah, Rohani Mohd, and Badrul Hisham. 2011. Is Religiosity an Important Determinant on Muslim Consumer Behaviour in Malaysia? Journal of Islamic Marketing 2: 83-96. [CrossRef]

Anderson, Norman H. 1971. Integration Theory and Attitude Change. Psychological Review 78: 171-206. [CrossRef] Anderson, Moji, Gillian Elam, Sarah Gerver, Ijeoma Solarin, Kevin Fenton, and Philippa Easterbrook. 2008. HIV/AIDS-Related Stigma and Discrimination: Accounts of HIV-Positive Caribbean People in the United Kingdom. Social Science and Medicine 67: 790-98. [CrossRef] [PubMed]

Aung, Steven K. H. 1996. Loving Kindness: The Essential Buddhist Contribution to Primary Care. Humane Health Care International 12: E12. [PubMed]

Bagozzi, Richard P. 2006. A Field Investigation of Causal Relations among Cognitions, Affect, Intentions, and Behavior. Journal of Marketing Research 19: 562-83. [CrossRef]

Blevins, John. 2015. Are Faith-Based Organizations Assets or Hindrances for Adolescents Living with HIV? They Are Both. Brown Journal of World Affairs 22: 25-38. 
Blevins, John. 2018. Christianity's Role in United States Global Health and Development Policy. Christianity's Role in United States Global Health and Development Policy. London: Routledge. [CrossRef]

Blevins, John, Christoph Benn, and Sandra Thurman. 2016. Reflections on HIV-Related Experiences of Two Global Funding Mechanisms Supporting Religious Health Providers. The Review of Faith E International Affairs 14: 110-17. [CrossRef]

Blevins, John B., Mohamed F. Jalloh, and David A. Robinson. 2019. Faith and Global Health Practice in Ebola and HIV Emergencies. American Journal of Public Health 109: 379-84. [CrossRef]

Breckler, Steven J. 1984. Empirical Validation of Affect, Behavior, and Cognition as Distinct Components of Attitude. Journal of Personality and Social Psychology 47: 1191-205. [CrossRef]

Bychkov, Oleg. 2019. 'He Who Sees Does Not Desire to Imagine': The Shifting Role of Art and Aesthetic Observation in Medieval Franciscan Theological Discourse in the Fourteenth Century. Religions 10: 205. [CrossRef]

Chatters, Linda M. 2002. Religion and Health: Public Health Research and Practice. Annual Review of Public Health 21: 335-67. [CrossRef] [PubMed]

Clobert, Magali, Vassilis Saroglou, and Kwang Kuo Hwang. 2015. Buddhist Concepts as Implicitly Reducing Prejudice and Increasing Prosociality. Personality and Social Psychology Bulletin 41: 513-25. [CrossRef] [PubMed]

Clobert, Magali, Vassilis Saroglou, and Kwang Kuo Hwang. 2017. East Asian Religious Tolerance versus Western Monotheist Prejudice: The Role of (in)Tolerance of Contradiction. Group Processes and Intergroup Relations 20: 216-32. [CrossRef]

Coursey, David H., and Sanjay K. Pandey. 2007. Public service motivation measurement: Testing an abridged version of Perry's proposed scale. Administration E Society 39: 547-68. [CrossRef]

Daly, Timothy M., and Rajan Nataraajan. 2015. Swapping Bricks for Clicks: Crowdsourcing Longitudinal Data on Amazon Turk. Journal of Business Research 68: 2603-9. [CrossRef]

Davidson, Richard J., and Anne Harrington. 2002. Visions of Compassion: Western Scientists and Tibetan Buddhists Examine Human Nature. Oxford: Oxford University Press.

Dlamini, Priscilla S., Thecla W. Kohi, Leana R. Uys, René Deliwe Phetlhu, Maureen L. Chirwa, Joanne R. Naidoo, William L. Holzemer, Minrie Greeff, and Lucy N. Makoae. 2007. Verbal and Physical Abuse and Neglect as Manifestations of HIV/AIDS Stigma in Five African Countries. Public Health Nursing 24: 389-99. [CrossRef] [PubMed]

Dorić, Dragan, Emilija Nikolić-Dorić, Vesna Jevremović, and Jovan Mališić. 2009. On Measuring Skewness and Kurtosis. Quality and Quantity 43: 481-93. [CrossRef]

Dotson, Michael J., and Eva M. Hyatt. 2002. Religious Symbols as Peripheral Cues in Advertising. Journal of Business Research 48: 63-68. [CrossRef]

Engstrom, David. 2005. The Roles of Buddhist Temples in the Treatment of HIV/AIDS in Thailand. Journal of Sociology and Social Welfare 32: 5-22.

Feldman, David B., Ian C. Fischer, and Robert A. Gressis. 2016. Does Religious Belief Matter for Grief and Death Anxiety? Experimental Philosophy Meets Psychology of Religion. Journal for the Scientific Study of Religion 55: 531-39. [CrossRef]

Fishbein, Martin, and Icek Ajzen. 2011. Predicting and Changing Behavior. London: Psychology Press. [CrossRef] Fuqua, Joy V. 2002. Religion as a Social Determinant of Public Health. Cultural Studies 16: 650-72. [CrossRef]

Genberg, Becky L., Surinda Kawichai, Alfred Chingono, Memory Sendah, Suwat Chariyalertsak, Kelika A. Konda, and David D. Celentano. 2008. Assessing HIV/AIDS Stigma and Discrimination in Developing Countries. AIDS and Behavior 12: 772-80. [CrossRef] [PubMed]

Genberg, Becky L., Zdenek Hlavka, Kelika A. Konda, Suzanne Maman, Suwat Chariyalertsak, Alfred Chingono, Jessie Mbwambo, Precious Modiba, Heidi Van Rooyen, and David D. Celentano. 2009. A Comparison of HIV/AIDS-Related Stigma in Four Countries: Negative Attitudes and Perceived Acts of Discrimination towards People Living with HIV/AIDS. Social Science and Medicine 68: 2279-87. [CrossRef] [PubMed]

Hackney, Charles H., and Glenn S. Sanders. 2003. Religiosity and Mental Health: A Meta-Analysis of Recent Studies: EBSCOhost. Journal for the Scientific Study of Religion 42: 43-56. [CrossRef]

Hassan Fathelrahman Mansour, Ilham, and Dalia Mohammed Elzubier Diab. 2016. The Relationship between Celebrities' Credibility and Advertising Effectiveness: The Mediation Role of Religiosity. Journal of Islamic Marketing 7: 148-66. [CrossRef] 
Hendriksen, Ellen Setsuko, Daniel Hlubinka, Suwat Chariyalertsak, Alfred Chingono, Glenda Gray, Jessie Mbwambo, Linda Richter, Michal Kulich, and Thomas J. Coates. 2009. Keep Talking about It: HIV/AIDS-Related Communication and Prior HIV Testing in Tanzania, Zimbabwe, South Africa, and Thailand. AIDS and Behavior 13: 1213-21. [CrossRef] [PubMed]

Hutchinson, Paul Lawrence, Xoli Mahlalela, and Josh Yukich. 2007. Mass Media, Stigma, and Disclosure of HIV Test Results: Multilevel Analysis in the Eastern Cape, South Africa. AIDS Education and Prevention 19: 489-510. [CrossRef] [PubMed]

Idler, Ellen L. 2015. Religion as a Social Determinant of Public Health. New York: Oxford University Press. [CrossRef] Jensen-Fangel, Søren, Lars Pedersen, Court Pedersen, Carsten S. Larsen, Palle Tauris, Axel Møller, Henrik T. Sørensen, and Niels Obel. 2004. Low Mortality in HIV-Infected Patients Starting Highly Active Antiretroviral Therapy: A Comparison with the General Population. Aids 18: 89-97. [CrossRef]

Johnny, Leanne, and Claudia Mitchell. 2006. 'live and Let Live': An Analysis of HIV/AIDS-Related Stigma and Discrimination in International Campaign Posters. Journal of Health Communication 11: 755-67. [CrossRef]

Khuat, Thu Hong, Thi Van Anh Nguyen, and Jessica Ogden. 2004. Understanding HIV and AIDS-Related Stigma and Discrimination in Vietnam. Hanoi: Institute for Social Development Studies and International Center for Research on Women.

Kitara, David Lagoro, and Judith Aloyo. 2012. HIV/AIDS Stigmatization, the Reason for Poor Access to HIV Counseling and Testing (HCT) among the Youths in Gulu (Uganda). African Journal of Infectious Diseases 6: 12-20. [CrossRef] [PubMed]

Kittikorn, Nilmanat, Annette F. Street, and Jeanine Blackford. 2006. Managing Shame and Stigma: Case Studies of Female Carers of People with AIDS in Southern Thailand. Qualitative Health Research 16: 1286-301. [CrossRef] [PubMed]

$\mathrm{Li}$, Li, Zunyou Wu, Yu Zhao, Chunqing Lin, Roger Detels, and Sheng Wu. 2006. Using case vignettes to measure HIV-related stigma among health professionals in China. International Journal of Epidemiology 36: 178-84. [CrossRef] [PubMed]

Mair, Victor H. 2006. Buddhism and the Rise of the Written Vernacular in East Asia: The Making of National Languages. The Journal of Asian Studies 53: 707. [CrossRef]

Mair, Victor H., and John Blofeld. 2006. Bodhisattva of Compassion: The Mystical Tradition of Kuan Yin. The Journal of Asian Studies 39: 161. [CrossRef]

Malamuth, Neil M., Scott Haber, and Seymour Feshbach. 1980. Testing Hypotheses Regarding Rape: Exposure to Sexual Violence, Sex Differences, and the 'Normality' of Rapists. Journal of Research in Personality 14: 121-37. [CrossRef]

Manoj, Sharma. 2015. Measuring Advertising Effectiveness (3 Methods). Hillsdale: L. Erlbaum Associates.

Mcgrath, Pam. 2007. Buddhist Spirituality-a Compassionate Perspective on Hospice Care. Mortality 3: 251-63. [CrossRef]

Miller, Tracy. 2015. Of Palaces and Pagodas: Palatial Symbolism in the Buddhist Architecture of Early Medieval Cave as Infinite Palace: South Asian Precedents and East. Frontiers of History in China 10: 222-63. [CrossRef]

Min Han, Chen. 2004. Testing the Role of Country Image in Consumer Choice Behaviour. European Journal of Marketing 24: 24-40. [CrossRef]

Morwitz, Vicki G., and Gavan J. Fitzsimons. 2004. The mere-measurement effect: Why does measuring intentions change actual behavior? Journal of Consumer Psychology 14: 64-74. [CrossRef]

Moyo, Philani, and Charlene Keir Ying-Ling. 2014. An Assessment of the Role of Faith-Based Organisations in HIV/AIDS Mitigation, Treatment and Care: The Case of Buddhist Compassion Relief in KwaZulu Natal, South Africa. Mediterranean Journal of Social Sciences 5: 345-51. [CrossRef]

Muralidharan, Sidharth, Carrie La Ferle, and Sanjukta Pookulangara. 2018. Studying the Impact of Religious Symbols on Domestic Violence Prevention in India: Applying the Theory of Reasoned Action to Bystanders' Reporting Intentions. International Journal of Advertising 37: 609-32. [CrossRef]

Nardella, Carlo. 2012. Religious Symbols in Italian Advertising: Symbolic Appropriation and the Management of Consent. Journal of Contemporary Religion 27: 217-40. [CrossRef]

Naseri, Abbas, and Ezhar Tamam. 2012. Impact of Islamic Religious Symbol In Producing Favorable Attitude Toward Advertisement. Revista de Administratie Publica Si Politici Sociale 1: 61-77.

Nyblade, Laura, and Kerry MacQuarrie. 2006. Can We Measure HIV/AIDS-Related Stigma and Discrimination? Current Knowledge about Quantifying Stigma in Developing Countries. Washington: Futures Group POLICY Project. 
Parker, Richard, and Peter Aggleton. 2003. HIV and AIDS-Related Stigma and Discrimination: A Conceptual Framework and Implications for Action. Social Science E Medicine 57: 13-24.

Patry Leidy, Denise. 1252. The Art of Buddhism. An Introduction to Its History and Meaning. Boston: Shambhala.

Peltzer, Karl, Warren Parker, Musawenkosi Mabaso, Elias Makonko, Khangelani Zuma, and Shandir Ramlagan. 2012. Impact of National HIV and AIDS Communication Campaigns in South Africa to Reduce HIV Risk Behaviour. The Scientific World Journal 2012: 384608. [CrossRef] [PubMed]

Putney, Snell, and Russell Middleton. 1961. Dimensions and Correlates of Religious Ideologies. Social Forces 39: 285-90. [CrossRef]

Rand, David G., Anna Dreber, Omar S. Haque, Rob J. Kane, Martin A. Nowak, and Sarah Coakley. 2014. Religious Motivations for Cooperation: An Experimental Investigation Using Explicit Primes. Religion, Brain and Behavior 4: 31-48. [CrossRef]

Ritter, Ryan S., and Jesse Lee Preston. 2013. Representations of Religious Words: Insights for Religious Priming Research. Journal for the Scientific Study of Religion 52: 494-507. [CrossRef]

Sayles, Jennifer N., Mitchell D. Wong, Janni J. Kinsler, David Martins, and William E. Cunningham. 2009. The Association of Stigma with Self-Reported Access to Medical Care and Antiretroviral Therapy Adherence in Persons Living with HIV/AIDS. Journal of General Internal Medicine 24: 1101. [CrossRef]

Scalvini, Marco. 2010. Glamorizing Sick Bodies: How Commercial Advertising Has Changed the Representation of HIV/AIDS. Social Semiotics 20: 219-31. [CrossRef]

Schroeder, John William. 2002. Visions of Compassion: Western Scientists Adn Tibetan BUddhists Examine Human Nature. New York: Oxford University Press.

Shiu, Henry, and Leah Stokes. 2008. Buddhist Animal Release Practices: Historic, Environmental, Public Health And Economic Concerns. Contemporary Buddhism 9: 181-96. [CrossRef]

Songwathana, Praneed, and Lenore Manderson. 2001. Stigma and Rejection: Living with AIDS in Villages in Southern Thailand. Medical Anthropology: Cross Cultural Studies in Health and Illness 20: 1-23. [CrossRef] [PubMed]

Song, Yao, and Zhenzhen Qin. 2019. Towards the Beauty of Buddhism: The Development and Validation of a Buddhist Aesthetics Scale. Religions 10: 343. [CrossRef]

St Lawrence, Janet S., Brenda A. Husfeldt, Jeffrey A. Kelly, Harold V. Hood, and Steve Smith. 1990. The Stigma of AIDS. Journal of Homosexuality 19: 85-102. [CrossRef] [PubMed]

Stewart, Neil, Christoph Ungemach, Adam J. L. Harris, Daniel M. Bartels, Gabriele Paolacci, and Jesse Chandler. 2015. The Average Laboratory Samples a Population of 7,300 Amazon Mechanical Turk Workers The Size of the MTurk Population. Judgment and Decision Making 10: 479-91.

Suki, Norazah Mohd. 2013. Green Awareness Effects on Consumers' Purchasing Decision: Some Insights from Malaysia. International Journal of Asia-Pacific Studies 9: 49-63.

Taylor, Valerie A., Diane Halstead, and Paula J. Haynes. 2010. Consumer Responses to Christian Religious Symbols in Advertising. Journal of Advertising 39: 79-92. [CrossRef]

Than, Phung Quoc Tat, Bach Xuan Tran, Cuong Tat Nguyen, Nu Thi Truong, Thao Phuong Thi Thai, Carl A. Latkin, Cyrus S. H. Ho, and Roger C. M. Ho. 2019. Understanding Global HIV Stigma and Discrimination: Are Contextual Factors Sufficiently Studied? International Journal of Environmental Research and Public Health 16: 1899.

Tran, Bach Xuan, Hai Thanh Phan, Carl A. Latkin, Huong Lan Thi Nguyen, Chi Linh Hoang, Cyrus S. H. Ho, and Roger Ho. 2019. Stigma against patients with HIV/AIDS in the rapid expansion of antiretroviral treatment in large drug injection-driven HIV epidemics of Vietnam. Harm Reduction Journal 16: 6.

UNAIDS. 2015. On the Fast-Track to End AIDS by 2030: Focus on Location and Population. Available online: https://www.unaids.org/sites/default/files/media_asset/WAD2015_report_en_part01.pdf (accessed on 1 May 2019).

UNAIDS. 2017. UNAIDS 2017. Available online: https://www.unaids.org/sites/default/files/media_asset/20170720_ Data_book_2017_en.pdf (accessed on 1 May 2019).

UNAIDS. 2018. UNAIDS DATA 2018. Available online: https://www.unaids.org/sites/default/files/media_asset/ unaids-data-2018_en.pdf (accessed on 1 May 2019).

Unger, Lynette S. 1995. Observations-A Cross-Cultural-Study on the Affect-Based Model of Humor in Advertising. Journal of Advertising Research 35: 66-71. 
van Dyk, Alta C. 2017. How Do Clergy in the Afrikaans-Speaking Churches Deal with Sexuality and HIV Prevention in Young People? Is the Message Clear? Verbum et Ecclesia 38: 1-9. [CrossRef]

Watts, Jonathan S., and Yoshiharu Tomatsu. 2012. Buddhist Care for the Dying and Bereaved. Needham Heights: Simon and Schuster.

Winchester, Daniel. 2017. 'A Part of Who I Am': Material Objects as 'Plot Devices' in the Formation of Religious Selves. Journal for the Scientific Study of Religion 56: 83-103. [CrossRef]

World Health Organization, and Unicef. 2015. GLOBAL HIV/AIDS RESPONSE Epidemic Update and Health Sector Progress towards Universal Access.

Yeung, Gustav K. K., and Wai Yin Chow. 2010. 'To Take up Your Own Responsibility': The Religiosity of Buddhist Adolescents in Hong Kong. International Journal of Children's Spirituality 15: 5-23. [CrossRef]

(C) 2019 by the authors. Licensee MDPI, Basel, Switzerland. This article is an open access article distributed under the terms and conditions of the Creative Commons Attribution (CC BY) license (http://creativecommons.org/licenses/by/4.0/). 